\title{
Fostering Regional Integration in Africa: The Case of Arusha-Namanga-Athi River Road Development Project*
}

\author{
Albert-Enéas Gakusi' ${ }^{1}$, Davide Sartori' ${ }^{2}$, Emmanuel Maliti ${ }^{3}$ \\ ${ }^{1}$ Independent Development Evaluation (IDEV), African Development Bank, Abidjan, Côte d'Ivoire \\ ${ }^{2}$ Center for Industrial Studies, Milan, Italy \\ ${ }^{3}$ Department of Economics, University of Dar es Salaam, Dar es Salaam, Tanzania \\ Email:a.gakusi@afdb.org, sartori@csilmilano.com,emmanuel.maliti@gmail.com
}

Received 13 November 2015; accepted 27 December 2015; published 30 December 2015

Copyright (C) 2015 by authors and Scientific Research Publishing Inc.

This work is licensed under the Creative Commons Attribution International License (CC BY).

http://creativecommons.org/licenses/by/4.0/

(c) (i) Open Access

\section{Abstract}

This case study aims at identifying operational challenges that are specific to multinational projects and the extent to which these projects contribute to fostering regional cooperation and integration. The study is based on the analysis of relevant documents and data mainly from the African Development Bank. It also draws on individual and focus group interviews carried out during a field work in Tanzania and Kenya between 3-15 July 2011. The Arusha-Namanga-Athi River Road Development Project was approved by the African Development Bank on 13 December 2006 for joint financing with the Japanese International Cooperation Agency (JICA). The overall project objective was to rehabilitate a major arterial trunk road with a regional bearing on trade and integration of the East African countries. The project has resulted in increased traffic flow, faster travel times, and lower vehicle operating costs. Development impacts such as increased cross-border trade, increased tourism and socio-economic development are still unfolding. Data on cross-border trade and other activities were not available, but interviews with stakeholders pointed to positive achievements. However, given the financing gap of about $45 \%$ in both countries to meet the cost of periodic maintenance of their road networks, sustainability of the road is at risk unless more pro-active measures are taken.

\section{Keywords}

Case Study, Regional Cooperation and Integration, Effectiveness, Efficiency, Impacts, Sustainability

\footnotetext{
*This paper has benefitted from very useful comments from : 1) Tesfaye Dinka, John Eriksson, and Fredrik Söderbaum, external peer reviewers; 2) Odile Keller, division manager in the Operations Evaluation Department (OPEV now IDEV); 3) the infrastructure experts of the Bank’s Field Offices, Lawrence Kiggundu, in Tanzania, and George Mukajuma, in Kenya; and 4) anonymous referees. The findings, interpretations, and conclusions presented in this paper are the sole responsibility of the authors.
}

How to cite this paper: Gakusi, A.-E., Sartori, D. and Maliti, E. (2015) Fostering Regional Integration in Africa: The Case of Arusha-Namanga-Athi River Road Development Project. Open Journal of Social Sciences, 3, 212-235. 


\section{Introduction}

This case study assesses the extent to which the Arusha-Namanga-Athi River Road Development project, hereafter the project (see the bold yellow line of Appendix 1), contributes to fostering regional cooperation and integration, including whether the expected benefits have materialized, and whether they are sustainable and equitably shared. The study also assesses project efficiency and seeks to understand the factors leading to success or failure as well as the lessons that can be learnt.

The evaluation is mainly based on the African Development Bank (The Bank)'s documents and data. It also draws on the results of a mission undertaken in Tanzania and Kenya from 3 to 15 July 2011. The mission team carried out interviews and focus groups with several stakeholders, including senior officials, local governments, local communities and road users. Interviews and the focus groups were based on a checklist to help answer the evaluation questions (Appendix 4). Also, phone interviews with nine prominent business associations or firms exporting and importing to Tanzania or to Kenya were carried out based on a structured questionnaire (Appendix 2). The selection of stakeholders for the semi-structured interviews was based on the knowledge of interviewees of the road conditions over time. The selection of the nine business entities for phone interviews has been carried out by the regional consultant on the basis of the interest of the latter in using the road.

The selection of stakeholders for the semi-structured interviews was based on the knowledge of interviewees of the road conditions over time.

At the time of the mission, the project was still ongoing, though almost completed. Hence, long term development impacts were still to materialise. A quantitative assessment of the results achieved so far in terms crossborder activities could not be carried out because of lack of relevant information. Bank's supervision mission reports available until July 2011 were used as main documentary evidence.

\section{The Regional Transport Sector}

The transport sector has larger economic importance in Kenya than in Tanzania. At the time the project was initiated in 2006, roads in Tanzania carried about $80 \%$ of total passenger traffic and $75 \%$ of total freight traffic, through a network of $86,472 \mathrm{~km}$, of which less than $8 \%$ was paved. Transport was estimated to account for $5.4 \%$ of GDP (United Republic of Tanzania 2008). In Kenya the transport network comprised about 195,000 km of roads, of which about $6 \%$ was paved. The sector represented $10.9 \%$ of GDP [1].

Regional transport policies aim at infrastructure development, accompanied by tariff reduction, elimination of non-tariff barriers and harmonization of procedures. Since 1998, the East African Community (EAC) has been highlighting the need to develop a modern regional road network, in order to improve regional trade and integration [2].

A Committee on East African Road Network Project was established and five road Corridors were identified as priority areas for action (Box 1). To facilitate trade along these Corridors, the EAC Treaty highlighted the necessity to eliminate non-tariffs barriers through harmonized standards, rules, procedures and practices [3]. The last two Five-Year EAC Development Strategies (2001-05 and 2006-10) reinforced the goal of achieving a customs union and a common market to facilitate trade, through the elimination of internal tariffs, the adoption of a Common External Tariff, and the unification of several custom administration offices into a single Trade and Customs Unit [4] [5].

EAC Partner States have implemented sector reforms aimed at a more efficient provision of services. These reforms include the formation of regulatory authorities and operational agencies, as well as privatization of operations [7]. In 1997, the Government of Tanzania (GOT) created the Tanzania National Roads Agency (TANROADS) and the Roads Fund Board (RFB) for, respectively, road maintenance and development operations, and for financing. With the Kenya Roads Act of 2007, Kenya established three new autonomous agencies,

\section{Box 1. Identified corridors.}

1. Mombasa-Malaba-Kigali-Bujumbura.

2. Dar es Salaam-Rusumo with branches to Kigali, Bujumbura and Masaka.

3. Biharamulo-Sirari-Lodwar-Lokichogio.

4. Nyakanazi-Kasulu-Tunduma with a branch to Bujumbura.

5. Tunduma-Dodoma-Namanga-Isiolo-Moyale* .

${ }^{*}$ Namanga-Athi River road is part of this corridor. 
each one responsible for maintenance and development of a given typology of road, namely: Kenya Nation Highways Authority (KeNHA), Kenya Rural Road Authority (KeRRA) and Kenya Urban Roads Authority (KURA). Moreover, A Road Investment Plan (2008-18) was designed to implement full harmonization of the legislative framework governing roads in Kenya. The Kenya Road Board (KRB) was established in 1999 to manage financial resources for road maintenance.

Despite increased allocation of funds (from around Tshs.170 billion in 2001/2002 to over 1100 billion in 2010/2011), transport in Tanzania is still characterized by inadequate capacity, leading to low accessibility, especially to rural areas, and high transport costs, such as long journey times and poor urban mobility. Another major challenge has to do with collection of the fuel levy, affected by widespread tax evasion (39\%, one of the worst collection rates in Sub-Saharan Africa), which hinders the securing of funds to operate and maintain roads. Similarly, although endowed with a larger network, Kenya public expenditure in transport is characterized by low rates of budget execution (60\% in 2006) and a large rehabilitation backlog, i.e. a gap in the financing available to operate and maintain the road network. Rural accessibility is also problematic, as only $30 \%$ of Kenyan population lives within two kilometres from an accessible road [8] [9].

\section{Project Objective and Description}

The core objective of the project is to improve the transport conditions of the existing road connecting Arusha, Tanzania, with Nairobi, Kenya (see Appendix 1). The project consists of the rehabilitation and reconstruction of the $242 \mathrm{~km}$ road (136 km in Kenya and $106 \mathrm{~km}$ in Tanzania) and the construction of a One-Stop-Border Post (OSBP) in Namanga. The improved road is designed to have both larger carriageway $(7 \mathrm{~m}$ width, surfaced with asphalt concrete) and shoulders ( $2 \mathrm{~m}$ width, surfaced with single bituminous). The One Stop Border Post is designed as the cordoning and fencing of an area of approximately 6.5 hectares to be designated as Border Control Zone (BCZ), within which access will be limited to persons, goods and services crossing the border (Box 2) [10].

The project is the result of a feasibility study started in 2003 and supported by the Bank with a grant of UA million through its Technical Assistance Fund (TAF). The feasibility study demonstrated the project's viability and readiness for implementation of the detailed engineering study [11]. After formal requests submitted by EAC's secretariat and governments of Kenya and Tanzania, the Bank mounted an appraisal mission in August 2006 to finance the project under the $\mathrm{ADF}^{1} \mathrm{X}$ Multinational Window. The Government of Japan through the Japan International Cooperation Agency (JICA) also agreed to co-finance the project and participated in the mission. The project was finally approved by the Board on 13 December 2006 for joint financing with JICA.

In line with the development challenges identified in the preceding section, the project is expected to to the establishment of major arterial trunk roads in order to facilitate cooperation and integration in East The road is of strategic importance as it is part of the priority Corridor N.5 of the EAC Regional Roads Network (Box 1 above), which spans from Tunduma in southern Tanzania to Moyale in northern Kenya, and onward to Addis Ababa.

Thanks to improved road conditions between Kenya and Tanzania, the project is expected to achieve positive development impacts. These include increased cross-border trade and tourism, increased socio-economic activities in the main towns of Arusha Namanga and Nairobi, and generation of new settlements along the road's path. These goals should support the regional integration process between the economies of the two countries. The principal beneficiaries are expected to be national and regional transport operators, cross border traders, the tourism industry in both countries, and the residents in the project’s influence area [12].

\section{Box 2. The one stop border post.}

An One Stop Border Post is a border post that combines two stops for national border control processing into one and consolidates border control functions in a shared space for exiting one country and entering another. It uses simplified procedures and joint processing wherever appropriate. Its realization is considered as key condition for full attainment of regional integration. In fact, the main purpose of the construction of an One Stop Border Post is to reduce the costs of cross-border transactions. In this way, it is expected to improve transport system reliability so as to help increase traffic capacity between countries.

Source: JICA (2012).

\footnotetext{
${ }^{1}$ For its assistance to its regional member countries, the African Development Bank Group uses three windows: the African Development Fund (ADF) which provides concessional loans and grants to low-income countries; the African Development Bank (AfDB) which provides non-concessional financing to credit-worthy countries and non-sovereign entities; and the much-smaller Nigeria Trust Fund (NTF) which provides concessional funding to low-income countries.
} 
In addition to the physical infrastructure, the project also comprises "soft" components, including two design studies for other cross-border roads between Kenya and Tanzania (Arusha-Holili/Taveta-Voi" and "Tanga-Horo Horo/Lunga Lunga-Mombasa-Malindi” roads), and two consulting services for capacity building. These latter concern the improvement of the technical capacity of the EAC with the recruitment and placement of two engineers into EAC's ranks upon project completion and the preparation of a report recommending how to improve contracting capacity in East Africa.

\section{Institutional Arrangements}

Governance structure. The project's governance involves a number of institutional actors at supranational, regional and national level. There are three executing agencies, one multinational Bank (AfDB) and one international donor (JICA). Two governments of sovereign countries and a regional development community, the EAC, are involved. TANROADS and KeNHA are the two governmental executing agencies responsible for road operations and development, respectively, for Tanzania and Kenya. The EAC is responsible for the implementation of the project's "soft" components. In addition, monitoring during implementation is enforced through AfDB's and JICA's programmed supervision missions.

Institutional arrangements. Two committees have been set up to streamline and enhance coordination. At the policy level, a Steering Committee ${ }^{2}$ (SC) is in charge of policy issues and project governance. Its responsibility is to decide on strategic actions helping governments of the partner states to reach an informed common decision. The SC is a temporary body, which meets twice a year and comprises the Permanent Secretaries and Chief Executive Officers of the executing agencies from Kenya and Tanzania. Decisions of the SC are submitted to the Sectoral Council of Ministers responsible for Transport, Communications and Meteorology (TCM) and eventually to the Council, the executing organ of the Community. Any issue that remains unresolved in the SC, beyond an agreed timeframe, is enforced through Council directives. With this mechanism the SC makes its actors accountable. At operational level, a Technical Committee ${ }^{3}$ (TC) facilitates, coordinates and monitors all technical aspects of the project and advises the Steering Committee, when necessary. In the TC each country is represented by a Coordinator Engineer who is responsible for day-to-day implementation activities. The TC meets quarterly [13].

Project management. Although designed as one unique operation, the project consists of two standalone contracts running independently from one another during implementation. Civil works and consultancy services for the supervision of the works have been packaged in two separate lots: Lot $\mathrm{T}$ "Arusha-Namanga section" in Tanzania and Lot K “Athi River-Namanga section” in Kenya, following separate tendering processes (Box 3). On the one hand, a unique design guarantees unity and coherence of the engineering parameters. On the other hand, two separate construction contracts share the risks associated to the project (e.g. negative political developments).

The EAC played a positive "pivotal" role in project preparation and implementation. Before project approval, it facilitated the whole process of project's preparation and in particular it contributed to mobilize funding from the Bank to support both design and preparation (grant) and implementation (loan). It thus played a key role in the upstream phase of the project cycle. During implementation, it is chairing both the Steering and the Technical Committees to keep overall project supervision and to ensure a smooth decision-making process. Although relatively complex, this governance structure contributes to keep all the actors under a common framework of mutual obligations and responsibilities and ensures coordination of activities.

\section{Box 3. Tendering of civil works.}

For Lot T, civil works contract was awarded to China Geo Engineering Corporation (for USD 52.3 million) with the contract signed on 13 June 2008 for a period of 36 months. J. Burrow South Africa was awarded the supervision contract (for USD1,648,980 + TZS 921,420,0 inclusive of taxes) with the contract signed on 20 June 2008. For Lot K, Gibbs Africa Limited was awarded the supervision contract for Euro 161,600 and KES189,669,620 net of taxes. The civil works contract was awarded to China National Overseas Engineering Corporation for KES6,208,685,234.74 for a 36 months contract period with the contract signed on 3 October 2007.

${ }^{2}$ The Steering Committee includes: the Secretary General of the EAC (Chairing), the Permanent Secretaries of EAC Affairs Ministries (Kenya and Tanzania), the Permanent Secretaries of Finance (for Kenya and Tanzania), and the Permanent Secretaries for Roads/Works for Kenya and Tanzania, respectively (Appendix 3).

${ }^{3}$ The Technical Committee consists of Deputy Secretary General (Projects and Programmes), EAC (Chairing), the Chief Engineer (Roads), KeNHA, the Director of Development, TANROADS, the Head of Infrastructure, EAC, the respective Country Coordinators/Project Engineers and Transport/Structure Engineer (EAC). 


\section{Costs and Financing, Implementation Schedule}

At appraisal, the cost of the project was estimated to be UA 98.516 million, of which 55.5\% allocated to Kenya, 40.9\% to Tanzania and 3.6\% to the East African Community. ADF loans amounting to UA 49.24 million and UA 0.54 million were approved to finance the project components in Kenya and Tanzania, respectively. JICA approved UA 39.71 million for financing of the component in Tanzania. The remainder (UA 0.05 Million for Tanzania and UA 5.4 million for Kenya) was provided by national counterpart funding. Finally, an ADF grant of UA 3.5 million was approved to the EAC to implement the project's soft components. Table 1 shows the project cost by component and financing sources. The project was expected to start in June 2007 and to finish in June 2010. Revised planned completion date (without the OSBP) is 31 June 2012 [7].

\section{Relevance}

The project responds to the needs of both Kenya and Tanzania to improve road transport infrastructure and to increase and deepen the links between their economies. The project is aligned with the EAC's Regional Development Strategy of support for the development of transport corridors. Civil servants from local governments and representatives of local communities have also identified inadequate infrastructure (especially transport and energy) as bottlenecks to regional development (Box 4). Stakeholders from the private sector reflected the same opinion, identifying poor infrastructure as one of the main challenges to growth and development, together with regulatory issues (customs, common standards), political instability and security, and poor skills.

However, although transport is still considered a top priority, private operators interviewed in Tanzania have identified energy as the leading bottleneck, immediately followed by roads, ports and railway. More specifically, given the current severe power shortages in the country, regional development initiatives could have facilitated grid connection between Tanzania, southern Africa and Uganda. In this way, surplus energy could have been exported to Tanzania rather than Tanzania reverting to emergency power supply which is unnecessarily expensive. On the Kenyan side, energy is ranked second, with roads and railways considered the first priority.

From the analysis of the project concept and logical framework, the relevance of the "soft" components and how they are aligned with the project's core objective is not explicit for all the components. The two study designs are synergic with the Arusha Namaga-Athi River road since they concern roads belonging to the same network of arterial trunk roads between Kenya and Tanzania holding a regional bearing. For instance, the Arusha-Holili/Taveta-Voi road is important for the import and export of Northern Tanzania since it connects the region of Arusha with the Mombasa port. On the face of it, the objective of the capacity building components is loosely connected to the achievement of the project's core objective. Indeed, the preparation of a report about the capacity of local contractors in East Africa has little to do with the increase of cross-border trade and tourism.

The project is also consistent with the Bank's central goal of supporting the transport sector in both countries. This is reflected by relative volumes of ADF approvals in their portfolios of operations (Box 5) [14] [15].

Table 1. Project cost and financing sources.

\begin{tabular}{lccccccc} 
& \multicolumn{2}{c}{ Tanzania } & \multicolumn{2}{c}{ Kenya } & \multicolumn{2}{c}{ EAC } & Total \\
\cline { 2 - 8 } Component & Source & $\begin{array}{c}\text { Amount } \\
\text { (UA million) }\end{array}$ & Source & $\begin{array}{c}\text { Amount } \\
\text { (UA million) }\end{array}$ & Source & $\begin{array}{c}\text { Amount } \\
\text { (UA million) }\end{array}$ & $\begin{array}{c}\text { Amount } \\
\text { (UA million) }\end{array}$ \\
\hline \multirow{2}{*}{ Physical realisation } & ADF & 0.537 & ADF & 49.241 & & & \\
Soft components & JICA & 0.054 & GoK & 5.472 & & & \\
Total & & & & & ADF & 3.500 & $\mathbf{9 8 . 5 1 6}$ \\
\hline
\end{tabular}

Source: African Development Fund (2006). Arusha-Namanga-Athi River Development Project, Appraisal Report.

\section{Box 4. EAC interviewee.}

The relevance of the project is confirmed by the fact that the road was already existing, and pretty much used. Intense use, especially for freight, was reported, and traffic was growing. The extremely poor conditions of the road were hampering such growth. 
Since 1998, the Bank's strategy in the EAC region has been oriented towards support for the development of the five EAC Corridors. Resources allocated to Tanzania under the ADF IX frame (UA 113 Million for 6 projects) were aligned with the need to strengthen road infrastructure with a particular focus on rural accessibility. For 2000-10, the Bank allocated UA 271.9 million to the transport sector in Tanzania, representing 26.8\% of the total country allocation. Likewise, the Kenyan Country Strategy Paper 2005-07 recognizes the importance of establishing an enabling environment to attract private investments, for which adequate road network is a precondition. Transport as a priority is confirmed by the sectoral allocation of Bank resources, accounting for almost 40\% (UA 385 million) of the total of Kenya's portfolio between 2000 and 2010 (Appendix 5).

\section{Quality-at-Entry}

Quality-at-Entry (QAE) was unsatisfactory. The project was designed as a multinational operation and some effort was made to harmonize the technical standards including carriageway width, pavements, surfacing, weighbridges, etc. This harmonization effort required preliminary dialogue and agreements at policy level, which took place within the coordination framework of the EAC. However, there were a number of deficiencies that had implications for the timing to attain the expected effects.

Forecasts in the appraisal report underestimated the actual costs as shown by subsequent estimates of the detailed engineering study [16]. This is also the case of the two design studies (Arusha-Holili/Taveta-Voi road and Tanga-Horo Horo/Lunga Lunga-Mombasa-Malindi road), which costs were higher than expected. As a consequence, contract values for both segments were higher than the amounts reflected in the loan agreements, which were based on the estimations made in the appraisal report. Since both AfDB and JICA portions of the financing remained unchanged, the additional funds needed had to be covered by the GoT and the GoK (this was of course in addition to meeting their other financial obligations such as taxes). These cost overruns reduced the project's economic viability, as calculated in the Addendum to Final Economic Report, dated September 2006 prepared by the consultants (JIBB consultancy service). The economic analysis of the project, originally submitted in September 2005, was indeed revised to reflect the prevailing economic situation due to increased costs of petroleum products.

The Economic Rate of Return (ERR) and the Economic Net Present Value (ENPV) were estimated at, respectively, 17.1\% and USD 26.42 million, by applying a social discount rate of $12 \%$ (Table 2). Thus, the overall economic viability of the project was confirmed at the ex-ante stage, but the cost overrun has worsened it. The unavailability of updated financial data, and the need to wait for actual costs at completion, prevents to recalculate the indicators and estimate the ex-post economic viability.

The implementation schedule was tight. In order to maintain the project's positive economic viability, the Appraisal Report states that "it is imperative that the whole project should be implemented immediately without delay". Accordingly, a tight implementation schedule was set up: five months from the Board's approval to the works contract signature and three years to complete construction. However, delays occurred before the project's took-off as well as during implementation, leading to low utilization ratios of the Bank's funds. Again, these delays have negative effects on the economic viability of the project, since they postpone in time the occurrence of benefits (and thus make the ENPV decrease).

The project preparation in Tanzania lacked a technical project review. In practice, owing to inadequate cost provisions at appraisal, works started without a review of the detailed engineering study. As consequence, some technical problems occurred during implementation. For instance, there was a bridge with inadequate size for the new road when the project started. Corrective measures to address this situation further delayed the project's implementation.

Information gathered from the interviews with stakeholders of both the public and the private sectors suggest that their involvement in design and implementation modalities was limited. The representatives from local governments and local communities affected by construction works declared to be involved only in the course of implementation, and only in cases of properties or environmental damage. Also, the private sector was not involved. None of the interviewed business associations and firms in Kenya and Tanzania was ever consulted in any of the project cycle stages. Even the East African Business Council (EABC), the regional private sector body, was not consulted by the project promoters. However, designing the rehabilitation of an already existing non-tolled road requires taking decisions which are of technical nature, rather than political, as it happens for example with new investments, where strategic decisions about location/route of the infrastructure, tariff policy, resettlements, etc. need to be taken. As a consequence, wider consultation of stakeholders would have had an 
Table 2. Summary of base case economic evaluation results.

\begin{tabular}{lcc}
\hline Road Section & ENPV (USD million) & ERR (\%) \\
\hline Arusha-Namanga & 13.89 & 19.5 \\
Namanga-Athi River & 12.53 & 15.7 \\
Overall project & $\mathbf{2 6 . 4 2}$ & $\mathbf{1 7 . 1}$ \\
\hline
\end{tabular}

Source: JIBB consultancy services, Addendum to Final Economic Report, September 2006.

impact in terms of larger awareness, but it is unlikely that the design would have been modified. Probably, the only technical parameter that could have changed is where to locate parking stations.

The most important weakness is that design for the implementation of the One Stop Border Post was not completed at the time of project preparation. The original feasibility study of 2003 designed the road without any provision to build a border post at Namanga because, at that time, the concept of One Stop Border Post was not yet on the political agenda. This came later on and the decision to add the One Stop Border Post was taken when the Bank mounted the appraisal mission in 2006. The intention was to finalize its design into the course of road implementation through a subsequent grant financing. Since no funds were available at the time of preparing the bidding documents in both Tanzania and Kenya, it was agreed that construction contracts would have made allowance for lump sums. These would have partly financed the OSBP, pending finalization of the detailed design study. However, this situation created an impasse resulting in overall implementation delays. In fact, the design of the One Stop Border Post was completed only in November 2010, with funding from JICA, when works on the road were already at an advanced stage. The further necessity to dialogue and agree on how to harmonize national-based standards and to introduce common computerized procedures to operate the custom added complexity and delays. This is the key bottleneck of the project, which delays the attainment of the expected benefits.

Currently, land acquisition, resettlement and compensation of the Project Affected People (PAP) have been completed on both the Kenyan and Tanzanian sides. The costs amount to USD 8.91 million and USD 2.68 million on the Kenyan and Tanzania sides, respectively. The high cost of compensation and resettlement is attributed to the significant development of private businesses on the Kenya side of the border. Specification of the harmonization of custom procedures to operate the facility is ongoing through bilateral agreements between governments, within the overall coordination of the EAC as facilitator of the dialogue. The construction of the One Stop Border Post facilities on both sides will be considered as addenda to the existing contracts [17].

\section{Effectiveness: Outputs, Outcomes and Development Impacts}

The attainment of objectives is satisfactory. The project generates a number of direct and indirect economic effects as shown in Table 3.

\section{Outputs}

Since it is still ongoing, not all the project's outputs have been realised. Concerning physical realisations, as of the date of the mission (July 2011), $99.84 \mathrm{~km}$ out of $104.20 \mathrm{~km}$ were surfaced and were open to traffic in Tanzania. In Kenya, $132 \mathrm{~km}$ of the $136 \mathrm{~km}$ were surfaced and were open to traffic. The One Stop Border Post was not yet in place.

As far as "soft" components are concerned, the two design studies have been completed. However, owing to cost underestimation of these studies, their costs were partly covered by transferring funds originally allocated for capacity building. This left inadequate resources for the capacity building components, including the recruitment of two engineers. These engineers were supposed to co-ordinate the execution of all project's components handled by the EAC, i.e. to coordinate the implementation of the road design studies as well as the study on contractors' capacity in EAC region. They were also supposed to continue working as EAC's staff after project completion. According to interviews, however, the non-realization of the capacity building components, and the missed recruitment of the engineers, has not affected the achievement of the project's core objective. The only, limited, impact was that coordination activities reverted to other engineers, already employed in EAC, who had additional work to perform. This suggests that the objectives of these components were not vital to the project’s development. 
Table 3. Project LogFrame and achievements.

\begin{tabular}{|c|c|c|c|c|c|c|}
\hline $\begin{array}{l}\text { Results Chain } \\
\text { Level }\end{array}$ & Effect & Indicator & $\begin{array}{r}\text { Baseline } \\
\text { (2004) }\end{array}$ & $\begin{array}{l}\text { Target } \\
\text { (2011) }\end{array}$ & $\begin{array}{l}\text { Actual } \\
\text { (2011) }\end{array}$ & Judgement \\
\hline \multirow{5}{*}{ Outputs } & $\begin{array}{l}\text { To rehabilitate the road } \\
\text { between Arusha and Athi River }\end{array}$ & $\mathrm{Km}$ of road & 0 & 242 & 232 & Positive \\
\hline & $\begin{array}{l}\text { To reduce cost of cross-border } \\
\text { transactions }\end{array}$ & N. of OSBP & 0 & 1 & 0 & Negative \\
\hline & $\begin{array}{l}\text { To study the feasibility of other } \\
\text { cross-border roads }\end{array}$ & $\begin{array}{l}\text { N. of cross-border road } \\
\text { design studies }\end{array}$ & 0 & 2 & 2 & Positive \\
\hline & $\begin{array}{l}\text { To improve the technical } \\
\text { capacity of the EAC }\end{array}$ & $\begin{array}{l}\text { N. of new engineers in } \\
\text { EAC's rank }\end{array}$ & 0 & 2 & 0 & Very negative \\
\hline & $\begin{array}{l}\text { To improve knowledge on } \\
\text { contracting capacity } \\
\text { in East Africa }\end{array}$ & N. of reports & 0 & 1 & 0 & Very negative \\
\hline \multirow{4}{*}{ Outcomes } & $\begin{array}{l}\text { To increase traffic between } \\
\text { Arusha and Athi River }\end{array}$ & $\begin{array}{l}\text { Annual Average Daily } \\
\text { Traffic (AADT) }\end{array}$ & - & $+36 \%$ & $+45 \%{ }^{*}$ & Positive \\
\hline & To reduce travel time & Travel time (minutes) & 240 & 150 & 150 & Very Positive \\
\hline & To reduce cost of trip & $\begin{array}{l}\text { Vehicles operating cost } \\
\text { (USD per vehicle } / \mathrm{km} \text { ) }\end{array}$ & 0.56 & 0.45 & 0.42 & Very Positive \\
\hline & To increase road safety & N. of accidents & - & - & - & Uncertain \\
\hline \multirow{3}{*}{$\begin{array}{l}\text { Development } \\
\text { Impacts }\end{array}$} & $\begin{array}{l}\text { To increase } \\
\text { cross-border trade }\end{array}$ & $\begin{array}{l}\text { Freight crossing the } \\
\text { border at Namanga } \\
\text { (tonnes/years) }\end{array}$ & 104,000 & 131,000 & - & Positive \\
\hline & To enhance tourism & $\begin{array}{l}\mathrm{N} \text {, of tourists crossing } \\
\text { the borders }\end{array}$ & - & - & - & Positive $^{* *}$ \\
\hline & $\begin{array}{l}\text { To boost socio economic } \\
\text { development }\end{array}$ & $\begin{array}{l}\mathrm{N} \text {, of new businesses } \\
\text { along the road }\end{array}$ & - & - & - & Positive $^{* *}$ \\
\hline
\end{tabular}

Note: Empty cells means data are not available. ${ }^{*}$ Data referred to Kenya section only. ${ }^{* *}$ Qualitative assessment. Source: From TANROADS and KENhA data.

\section{Outcomes}

While there is no data available for Tanzania, Table 4 shows that on the Kenyan road section the Average Annual Daily Traffic (AADT) between June 2004 and April 2010 has dramatically increased (+45\%). The majority of passengers using transport facilities are engaged in business relating to cross border activities between Kenya and Tanzania. Part of this increase (approximately 5\% - 10\% as declared by the interviewees) is due to the project which has generated new traffic by reducing the generalised cost of transport.

Travel time savings: Improved road conditions have the direct effect of reducing travel time for road users (Table 5). Interviews carried out in Tanzania and Kenya indicated that the rehabilitation of two road sections has almost halved the time required to travel from Arusha to Namanga and from Namanga to Nairobi, while the number of days required for trucks has fallen from 4 to 1 . At present, the benefit is still mainly experienced within the national borders. When the One Stop Border Post is operational, travel time for long distance passengers (from one country to the other) and freight crossing the countries will be further reduced, thus contributing to increased cross-border trade.

According to minibus drivers and a representative of the Kenya Long Distance Truck Drivers Association, the costs that depend directly on using the vehicles (tire changing, car repairs, etc.) decreased thanks to improved road conditions. Rough estimates provided by interviewed respondents indicate a decrease of vehicle operating costs of about $20 \%-30 \%$. According to baseline data provided in the appraisal report, this would mean a decrease of vehicle operating cost from USD 0.56 vehicle $/ \mathrm{km}$ to USD 0.42 vehicle $/ \mathrm{km}$. Vehicle operating costs considered here do not include fuel consumption since this is mainly related to traffic congestion and not to road conditions.

The net effect on road safety is controversial and still to be verified. On the one hand, wider carriageway and shoulders, together with better visibility, are safer than a narrow road. On the other hand, better road conditions encourage users to drive at higher speed. In these conditions, low education concerning road safety can lead to 
Table 4. Increase in traffic on Athi River-Namanga Road (Kenya).

\begin{tabular}{|c|c|c|c|c|c|c|c|c|c|c|}
\hline Year & Total & $\begin{array}{l}\text { Motor } \\
\text { cycles }\end{array}$ & Cars & $\begin{array}{l}\text { Pickups, Jeeps, } \\
\text { 4WDs, Vans }\end{array}$ & Minibus & Buses & $\begin{array}{c}\text { Light } \\
\text { Trucks }\end{array}$ & $\begin{array}{c}\text { Medium } \\
\text { Trucks }\end{array}$ & $\begin{array}{c}\text { Drawbar } \\
\text { Trucks }\end{array}$ & $\begin{array}{c}\text { Agricultural } \\
\text { Tractors, } \\
\text { Graders, etc. }\end{array}$ \\
\hline 2004 & 6196 & 27 & 2373 & 1442 & 1616 & 168 & 110 & 317 & 138 & 5 \\
\hline 2010 & 8957 & 77 & 2913 & 1866 & 1507 & 259 & 508 & 426 & 692 & 10 \\
\hline Increase (\%) & 45 & 185 & 23 & 29 & -7 & 54 & 362 & 34 & 401 & 100 \\
\hline
\end{tabular}

Source: GIBB, Kajiado observation, Kenya.

Table 5. Travel time savings before and after the intervention.

\begin{tabular}{lcc}
\hline Section & Before (minutes) & After (minutes) \\
\hline Arusha-Namanga & 100 & 60 \\
Namanga-Athi River & 140 & 90 \\
\hline
\end{tabular}

Source: interviews.

an increased number of accidents, especially in the areas populated with animals crossing the road and in urban centres. One of the interviewees has argued that "with the road in worse conditions, there were fewer accidents, because vehicles could not over speed". This risk was already foreseen in the Environmental and Social Impact Assessment (ESIA), which envisaged a series of mitigation measures including improved parking bays, provision of services roads on busy areas, provision of pedestrian crossing on bridges and high gorges, widening of the road in some places to allow for bicycle paths and pedestrian sidewalks. As of the mission's date, these facilities were not built, but later information gathered from the Bank's project managers indicate that they have been constructed since then. However, any reliable assessment about the actual project's effect on accidents would require a track of statistical information, which is not yet available.

\section{Development Impacts}

The project's core development impact is the facilitation and increase of cross-border trade [18]. The border crossing at Namanga is very important for trade between Tanzania and Kenya. According to the ADF Appraisal Report, $41 \%$ of exports to Tanzania and $20 \%$ of Tanzania's exports to Kenya pass through Namanga. The Appraisal Report expected that trade volumes of freight crossing the Namanga border would have increased by 26\%, from 104,000 tonnes in 2006 to 131,000 tonnes in 2010. This would result from a combination of demographic and economic growth and the reduction of transport costs generated by the rehabilitated road. Quantitative information to assess the actual effects of the project on trade is still very limited. However, stakeholders said that "cross-border activities are increasing thanks to the improved road infrastructure, which makes possible more business trips in less time at a lower cost". Interviewees also mentioned that "trend of cross-border activities through unofficial routes is going to be reduced thanks to the rehabilitated road". The full attainment of this objective will also depend on the actual establishment of the One Stop Border Post and the harmonisation of custom and business procedures [19] [20].

Socio-economic development: housing dynamics, new settlements and land valorisation are unfolding. Increased business opportunities are attracting population to the districts along the road. New settlements have emerged notably in Longido, Tanzania, due to increasing internal and cross border trading activities and because people from Arusha are investing in housing while continuing to work in Arusha. This is also the situation in agglomerations next to Nairobi, such as Kitengela. In general, small business clusters are being set up along different parts of the road. Land and real estate prices have drastically increased in some agglomerations along the road and secondary and tertiary activities such as cement, steel, and animal feed plants, and universities are being set up. Although all these effects cannot be attributed to the project alone, it is likely that in the absence of the project, fewer business opportunities would have emerged, the movement of population would have been constrained, and competitiveness reduced owing to higher transport costs [21]. 
The road would benefit the tourism economy at regional level because it improves accessibility to major tourist attractions including Mt. Kilimanjaro, Arusha National Park, Amboseli National Park and Chyulu Game Reserve. According to 2005 estimates, i.e. before project's implementation, 24\% of all tourists' arrivals in Tanzania entered through Namanga, having travelled on the project road. With the road in good conditions, this data is expected to grow significantly. In particular, the road offers to tourists a reliable transport mode alternative to air in order to access the major tourist attractions of the area [22].

\section{Environmental Impact}

The road passes through an area of very low population density, supporting Maasai pastoralist groups. As identified in the Environmental and Social Impact Assessment, the project should generate limited negative impacts on environment, mainly related to damages during construction. However, evidence collected at Mavoko (Kenya) city council suggests that damages occurred in the agglomeration of Kitengela have been of an exceptional magnitude. These consisted of village and feeder roads destruction due to the passage of heavy vehicles and trucks, which had to use these roads as by-pass during construction. This issue was not foreseen upfront by the ESIA and, consequently, no mitigation measures were identified [17].

\section{Distribution of Benefits}

Both countries will benefit from improved road infrastructure conditions, as traffic will be more fluent on both directions and trade facilitated on a regional basis. As far as gains from trade are concerned, reduced transport costs usually enhance export opportunities, strengthen competition and widen productive factor markets [23]. Since there has always been a significant imbalance in trade between the two countries, with Kenya in a prominent position mainly because of its stronger manufacturing base, it is likely that the improved transport and transit operations will facilitate the further expansion of Kenyan exports to Tanzania, especially in the short and medium term. However, the price-reduction effect arising from the reduction of transport costs will also lead to greater benefit for Tanzanian consumers of imported goods from Kenya. The magnitude of this effect depends on the kind of goods traded, as well as on the size and the competiveness of the market concerned (Box 6). Further, concerning governmental revenues, it is plausible that Tanzania will accrue a higher return. This will be determined by the different value of the goods exchanged, which is higher for freight exported from Kenya to Tanzania, and consequently through the application of higher unit taxes to the typologies of goods entering Tanzania.

Respondents from private sector also believe that the project has greater impact on tourism industry in Kenya than in Tanzania. First, this is because the priority in Tanzania rests on linkages between northern and southern national tourist circuits. Second, road facility linking efficiently Nairobi and Arusha may have even potentially negative effects on tour operators' business in Tanzania. One respondent, for example, indicated that "we actually prefer the road to be in bad shape so that tourists land in Kilimanjaro International Airport, instead of landing in Kenya and then drive to Arusha". Vice-versa, tour operators in Kenya may exploit the road in good condition and increase their business by organizing trips to Arusha region from Nairobi.

As far as distribution of benefits among stakeholders is concerned, the project generally brings positive effects. All road users, such as truck drivers, cross-border traders, transport operators (e.g. minibus, matatu, etc.)

Box 6. Trade developments between Kenya and Tanzania.

Kenya is a net exporter to Tanzania and the other EAC Partner States. According to Tanzania’s Government’s Economic Survey 2013, Kenya total export to Tanzania in 2013 accounted for about US\$ 303.6 million, with a positive net balance of US\$ 227.1 million. The road connecting Arusha to the capital Nairobi is one of the main axis along which cross border trading activities are performed.

Tanzania’s total exports to the entire EAC region increased from US\$ 315.6 million in 2008 to US\$ 419.3 million in 2013 . Imports from other EAC members to Tanzania have also increased over time, from US\$204.8 million to US\$ 359.1 million over the same period. The EAC region is therefore a net importer to Tanzania. Major exports to Tanzania comprise of iron and steel, animal and vegetable fats, plastics, mineral fuels and aluminum. Major imports from Tanzania include paper and paperboard, textiles and worn clothing, cereals, wood, cotton and vegetables. However, this increase in total trade is also attributed to improvement in data collection following automation of major entry points bordering with other EAC Partner States, including the Namanga entry point.

The main imported goods from Kenya include petroleum products, aluminum, motor vehicles, iron and steel. Tanzania's exports to Kenya textile articles, worn clothing, tea, coffee, mate and spices [6]. 
and private cars benefit from road's rehabilitation [24]. Also, population resident in areas next to the project benefit from land and real estate price increase, as well as from new secondary and tertiary activities being set up along the corridor. However, a category of stakeholders which is experiencing a relative loss are the local administrations located along the road. When the road was in bad conditions, they used to set-up access barriers, lorry parks and matatu terminus in order to collect revenues. With the new road designed as a high-speed international road without physical barriers, this source of revenues is being lost.

\section{Efficiency}

Overall, the project implementation is efficient, although with some delays and cost overruns resulting from some predictable and unpredictable adverse events. Since project implementation is being carried out through single independent contracts, the detailed analysis of the implementation performance is also structured separately for the two countries (Table 6 and Table 7).

a) Tanzania section: Arusha-Namanga

Procurement process was delayed as compared to the initial time schedule. The main cause of delay before project commencement was related to the procurement process. About one and a half year was spent on procurement, against the six months planned. Civil works contract was signed on June 2008 against planned June 2007. This was due to diverging interpretations between the Bank and TANROADS on some technical aspects of the bidding. This has led to extended time to obtain the Bank's non-objection. However, to partially mitigate this negative performance, it must be recalled how the implementation schedule imposed a tight deadline on the execution of all tendering activities and fulfilment of the conditionalities of the Bank [25].

Expected cost at completion is in line with forecasts, although the project progress is behind the planned schedule. In July 2011, the reported slippage was of 156 calendar days. According to the latest data available, overall progress of civil works stands at $78.52 \%$ against the originally planned $93.61 \%$. The contract time elapsed to-date was 1082 calendar days or 98.81\%. Given the expected works completion dated 13 July 2011, the Contractor (China Geo Engineering Corporation) requested and certified an extension of time of 156 calendar days, with new expected date of completion set in December 2011. Including the construction of the OSBP, the work completion date is expected by January 2013.

The analysis of major causes of delay shows that these are technical in some cases and institutional in others. The most important cause of delay was the flooding, which could not be foreseen. Other causes, on the contrary, could have been avoided if adequately addressed during the project design and preparation stage. For instance, another daunting, but predictable, implementation constraint was the delayed GoT counterpart payments which has pre-empted the contractor to timely execute the work. Table 6 provides a detailed review of problems encountered and the corrective measures implemented.

Overall, despite the potential right to stop the works, the contractor could keep fairly good working relationships with the supervision contactor (J. Burrow) and the executing agency (TANROADS). This behaviour was a key determinant allowing to overcome project implementation challenges. Other positive factors included the presence of a regional manager from TANROADS in the field, who acted as constant reference point for the contractor and the supervision consultant so as to speed up the decision-making process.

b) Kenya section: Namanga-Athi River

The procurement process has been managed smoothly and timely. ADF loan has been approved in February 2007, the tender launched in March and the selection of candidate in September 2007. On $3^{\text {rd }}$ October 2007, the civil works contract was signed for a 36 months period, representing 3-months delay against the planned schedule.

Implementation progress is behind the planned schedule and costs have been overrun. In July 2011, overall progress stood at $89 \%$, against the originally planned $100 \%, 132 \mathrm{~km}$ of the $136 \mathrm{~km}$ had been surfaced and was open to traffic. The Contractor has obtained two extension of time for a total of 214 calendar days. Expected cost at completion is estimated at $116 \%$ (allowing the whole contingency sum to be consumed). Including the construction of the OSBP, the expected date of completion is August 2013.

The analysis of the major causes of delay and cost overruns shows that they range from political to procedural and financial reasons. The most daunting problems were due to uncontrollable circumstances such as the political situation prevailing after the disputed presidential election of 27 December 2007 in Kenya, and the strikes of the workforce. Also, the most important predictable factor hindering implementation performance was 
Table 6. Arusha-Namanga section. Problems faced during implementation and project management response.

\begin{tabular}{|c|c|c|c|}
\hline Problem & Nature & Predictability in the design phase & Proposed corrective measure \\
\hline $\begin{array}{l}\text { Flood overtopping } \\
\text { During February 2011, the } \\
\text { road was overtopped by } \\
\text { flood waters at five locations } \\
\text { causing significant } \\
\text { damages to the works. }\end{array}$ & Technical & $\begin{array}{l}\text { NO. The design consultants have been } \\
\text { approached and have inspected the locations } \\
\text { coming to the conclusion that the capacities of } \\
\text { the designed drainage structures were adequate. } \\
\text { Considered that the area where the project } \\
\text { takes place is a semi-arid land, the likelihood } \\
\text { of occurrence of such an event is about one } \\
\text { each ten years. A different project design, } \\
\text { explicitly envisaging this event, would have } \\
\text { not been consistent with standard } \\
\text { specifications. }\end{array}$ & $\begin{array}{l}\text { It was agreed that the supervision } \\
\text { consultant mobilizes a hydrologist to } \\
\text { immediately review the capacities of } \\
\text { the structures at the said locations and } \\
\text { recommend corrective measures and } \\
\text { cost implications. The report of the } \\
\text { hydrologist should be shared with the } \\
\text { Bank. The Contractor should be } \\
\text { instructed without any further delay } \\
\text { for the additional crossings where } \\
\text { there is capacity inadequacy. }\end{array}$ \\
\hline
\end{tabular}

\section{Paving surface defects}

On October 2010, asphalt surface defects, in terms of regularity of the thickness, have been noted between

km32+000-41+000;

km50+000-54+000; and

km89+000-94+000.

\section{Bridge width}

The kerb to kerb width of the bridge at km72+000 is $29.4 \mathrm{~m}$ far below $36.6 \mathrm{~m}$, the width required to cover the carriageway and the usable shoulders.

Technical

NO. The design of the paving surface has been assessed as adequate. The defects are due to a Contractor's error.

Technical

YES. The bridge was already existing and provisions on how to widen it should have been included in the project design.

\section{Delays on GOT} counterpart financing

GOT has only partially met its obligations. GOT portions of the invoices n. 7 13 are still not paid, for a total amount of TZS. 239.3 million and USD 1.05 million.

As a result the Contractor gave a notice to reduce the rate of work in accordance with the contract conditions.

\section{Absence of experienced skilled manpower \\ The Contractor is facing difficulties to recruit foremen, masons and excavators to engage on landscaping works.}

YES. In the initial financing agreement GOT financing was limited to only part of the supervision consultancy contract, and not the civil works, for a total counterpart funding equal to UA 0.054 million (about $0.13 \%$ of the combined cost of civil works and consultancy services). However, since ADF and JICA loans have been issued before the execution of more accurate cost estimates and the contract price was higher than the amounts agreed, GOT had to cover the cost over and above the available financing from JICA and ADF, as well as taxes. GOT counterpart, including taxes, accounts today to UA 5.8 million. Given the difficulties the national treasury is encountering to face its various commitments to roads development and maintenance, more accurate cost estimates at appraisal stage would have prevented the necessity to mobilize national funds.

YES. Given the in-depth knowledge of TANROADS about the socio-economic context of Arusha region, including the local labour market, a more accurate plan for

Technical recruitment of local labour force could have been elaborated and included in the contract so as to bind the Contractor to some specifics guidelines.
It is agreed that the Contractor rectifies the defects at its own cost.

The Executing Agency, in agreement with the advised of the AfDB task manager, accepts to widening the bridge to provide walkways on either side for pedestrians. The Contractor and the Consultant agree on the equipment to purchase.

The Contractor forwarded repeated notice on the delay of the IPCs seeking for immediate payment. He also notified that his progress was affected due to this cash flow shortage. The Employer has been asked to take the necessary action before the Contractor takes serious measures.

Apart from that, no particular action has been undertaken at political or institutional level, e.g. by the EAC, to induce GOT to fulfill its requirements.

The Consultant is pushing the Contractor to mobilize additional excavators, employ sufficient and experienced manpower (foremen and masons) and/or sublet to the specialized sub-contractors to expedite the lined drain work. 
Table 7. Namanga-Athi River section. Problems faced during implementation and project management response.

\begin{tabular}{|c|c|c|c|}
\hline Problems & Nature & Predictability in the designing phase & Proposed corrective measure \\
\hline $\begin{array}{l}\text { Delayed payments from ADF } \\
\text { As of December 2010, invoices } \\
\text { n. } 17 \text { and } 18 \text { were paid very } \\
\text { late and n.19 is yet to be paid } \\
\text { by the Bank, yet GOK has paid } \\
\text { its part. }\end{array}$ & Procedural & $\begin{array}{l}\text { YES. The procedure to pay a certified } \\
\text { invoice can take up to } 6 \text { months. } \\
\text { Although independent from the } \\
\text { project implementing bodies, this } \\
\text { event is assessed as predictable since } \\
\text { it concerns well-established } \\
\text { procedures existing between GOK } \\
\text { and AfDB. }\end{array}$ & $\begin{array}{l}\text { The contractor has stopped the works } \\
\text { or reduced the rate of activity in } \\
\text { several occasions until the payments } \\
\text { were processed. To respect the } \\
\text { implementation schedule, } \\
\text { financial resources have been } \\
\text { borrowed from China Bank. } \\
\text { AfDB task manager promised that the } \\
\text { Bank will do the necessary so that } \\
\text { payments will no longer be delayed. }\end{array}$ \\
\hline Adverse climatic condition & Technical & $\begin{array}{l}\text { NO. The level of rainfalls occurred } \\
\text { between September } 2009 \text { and April } \\
2010 \text { was of an exceptional nature. }\end{array}$ & N/A \\
\hline $\begin{array}{l}\text { Variation of prices } \\
\text { The trend for variation of } \\
\text { prices indicates a projected } \\
\text { completion amount } 326 \% \\
\text { above the contingency } \\
\text { allowed for in the contract. }\end{array}$ & Financial & $\begin{array}{l}\text { YES. A study of the current inflating } \\
\text { trends of goods and services could } \\
\text { have provided more accurate } \\
\text { estimates about the magnitude of the } \\
\text { financial contingency. }\end{array}$ & $\begin{array}{l}\text { The Bank's supervision mission } \\
\text { advised that the indices for the Varia- } \\
\text { tion of Prices need to be reviewed on } \\
\text { the basis of the actual indices, as some } \\
\text { of them look to be on the higher side. }\end{array}$ \\
\hline Post-election violence & & & \\
\hline $\begin{array}{l}\text { After the disputed presidential } \\
\text { election of } 27 \text { December } 2007 \\
\text { the port of Mombasa has been } \\
\text { closed due to violence and } \\
\text { demonstrations. }\end{array}$ & Political & NO. The fact could not be predicted. & N/A \\
\hline $\begin{array}{l}\text { Illegal strikes of the recruited } \\
\text { local manpower }\end{array}$ & Political & NO. The fact could not be predicted. & N/A \\
\hline
\end{tabular}

Source: Authors elaboration.

the delayed payments from the ADF due to lengthy Bank's procedures to pay certified invoices. One factor which led to overcome project implementation challenges was that the contractor, who got his first assignment in Kenya, was committed to make special efforts to achieve the desired results in order to establish a good reputation, a "Fare bella figura" according to Hirschman (1967) [26]. Other key factors were: an efficient management of the supervision consultant consisting of a meeting every Monday to plan the weekly activities; skilled team and a good enforcement of the standardized procedures; and good relationship held with local communities thanks to the provision of some basic goods such as water to hospitals, food during holidays, etc.

To sum up, given the magnitude of the cost overrun and delays, which are within a reasonable order, and considering that several implementation obstacles were external and not predictable by the project management, the project is assessed to be efficiently implemented. The implementation is slightly more efficient in Kenya than in Tanzania, where it suffered from a late take-off (Table 8).

\section{Sustainability}

Sustainability is at risk due to weak capacity for roads maintenance. As of the mission date, both countries were experiencing a financing gap of about 45 percent of financial resources needed to meet the cost of periodic maintenance of their road networks (Box 7). The current maintenance policy of trunk and regional roads is to prioritize the preservation of all roads that are already in good condition by channelling funds to cover their full routine (day-to-day) and periodic (each 7 - 8 years) maintenance. This policy is generally referred to as "to maintain the maintainable first". The basis for this policy is that in the past, neglecting to repair simple road failures over time, led to full scale deterioration of the roads, which eventually required capital investment for rehabilitation and reconstruction, as in the case of the Arusha-Namanga-Athi River road [27]. 
Table 8. Expected versus actual costs and timing.

\begin{tabular}{lll}
\hline & Expected & Actual \\
\hline \multirow{2}{*}{ Duration of procurement } & Tanzania: 5 months & Tanzania: 18 months \\
& Kenya: 5 months & Kenya: 8 months \\
Duration of civil works ${ }^{*}$ & Tanzania: 36 months & Tanzania: 42 months \\
& Kenya: 36 months & Kenya: 46 months \\
Cost & Tanzania: UA 40.3 million & Tanzania: N/A \\
& Kenya: UA 54.7 million & Kenya: UA 61.8 million \\
\hline
\end{tabular}

*Excluding the OSBP. Source: AfDB supervision mission summaries.

Box 7. Road maintenance systems in Tanzania and Kenya.

In Tanzania, the Road Fund Board (RFB) is responsible for funding road maintenance activities. Funds allocation between implementing agencies is based on maintenance needs: $70 \%$ of the Fund is provided to TANROADS for maintenance of trunk and regional roads; $30 \%$ is given to local authorities for maintenance of the district, feeder and service roads. Sources of RFB financing are $96 \%$ through fuel levy and $4 \%$ though traffic charges (i.e. fees paid for cross-border traffic), overloading fees and freight vehicle license fees. Thus, the overall Fund budget depends on both fuel consumption and traffic flows. The Fuel levy for the financial year 2010/11 is fixed at 200 Tzs per litre (about 0.12 USD).

The total maintenance needs for the whole road network in Tanzania for financial year 2010/11 are Tshs.479.56 billion (about 298.4 USD million), while the expected revenue for maintenance for the same period is Tshs.262.03 billion (about 163.0 USD million). In other words, the Fund can currently cover only about $55 \%$ of the requirements. The $45 \%$ financial gap, in particular affect periodic maintenance which prevents reconstruction later on. Thus, due to the existence of a huge backlog of maintenance (totalling Tshs.216 billion annually for a period of 5 years), and in order to close the gap within a period of three years, RFB has proposed to increase fuel levy by Tzs. 50/litre. The levy increase is also needed to compensate for value loss resulting from inflation and depreciation of Tanzanian shilling. However, this proposal was not adopted due to the resistance of the government which did not want the measure to affect its political consensus [28] [29].

In Kenya, funding for road maintenance is provided by the Kenya Road Board (KRB), established and operational since 1999. KRB allocates funds to autonomous road agencies for the maintenance, rehabilitation and development of the categories of roads in respect of which they are designated for: $32 \%$ is allocated to the Rural Roads Authority; $40 \%$ to KenHa; $15 \%$ to the Urban Roads Authority; $1 \%$ to Kenya Wildlife Service; $2 \%$ for the recurrent expenditure of the Board; and the remainder $10 \%$ is allocated annually, with the approval of the Minister, to different road investment priorities derived from the five-year road investment programme. In financial year 2010/11 KRB expects an annual revenue of Ksh.27.3 billion (about 300 USD Million), 99\% of which comes from fuel levy. Current fuel levy is 0.10 USD per litre of petrol and diesel consumed.

With total maintenance needs for the whole road network in Kenya (about 160,000 km) assessed at Ksh.50.0 billion (about 550 USD million) for financial year 2010/11, the Fund can cover only about 55\% of the requirements, with a financial gap of $45 \%$. Given this constraint, in order to have (sub) optimal budgetary allocation, KRB has developed a "cyclical” approach to maintenance, which is reflected in the national Road Sector Investment Programme. Accordingly, all roads are reviewed, listed and prioritized on the basis of a set of criteria such as road condition, level of traffic, location, exposure to weather (activities) and so on. The system is intended to have a concrete and more accurate financing mechanism, to mitigate the lack of financial resources.

Source: http://www.krb.go.ke; http://www.roadsfundtz.org/web/index.asp

Since it has just been rehabilitated, the Arusha-Namanga-Athi River road is likely to be prioritized by Governments so as to obtain routine maintenance immediately after defect liability period expires, and periodic maintenance, which will become due until 7 - 8 years after construction (around 2020). However, both countries face a problem of limited resources in the face of road maintenance needs and the possible political preference of new investments to maintenance. If not adequately maintained, the road will fall in the group of "poor roads" for which maintenance is not assured.

\section{Conclusions}

The Arusha Namanga-Athi River Road Development Project is a project of regional importance which is a part of the African highway from Cairo in Egypt to Cape Town in South Africa. It is already producing expected results in terms of increased traffic, travel time savings, vehicle operating costs reduction. It is likely to produce increased cross-border movement of people and exchange of goods and services between countries. The road is also fostering development of economic activities. New settlements and small business clusters have emerged along different parts of the road and touristic activities increased. There has been an increased secondary and tertiary activities and high population growth in some agglomerations notably next to Arusha and Nairobi. 
Weak design aspects including late design of the OSBP, cost underestimation, lengthy Bank's procedures and delayed counterparts funding, have produced time and cost-overruns during implementation. However, since several implementation obstacles were not predictable by the project management (e.g. the political situation prevailing in Kenya after elections of December 2007 and the flooding in Tanzania), the project could be considered to be efficiently implemented.

Factors that allowed overcoming obstacles included:

- The advisory services of the Bank's Field Offices experts;

- The contractor's commitment to high performance, with a view of establishing a good reputation in the region;

- The good working relationships kept between contractors, consultants and executing agencies;

- The constant presence of representatives from the executing agencies.

Capacity building components have not been realised. However, this was not a serious obstacle to the realisation of the core objective of the project to reduce transport cost in order to facilitate cross-border activities between Kenya and Tanzania. This reflects a loose connection between the capacity building components and the project's overall rationale. The governance structure of the project has contributed positively to the project development, both during the project design and implementation phases. The EAC played a pivotal role as a regional coordinator and supervisor.

Lack of inclusion of provisions for the One Stop Border Post within the original project design proved to be a major constraint delaying the expected regional integration effects of the road. The implementation of the One Stop Border Post requires setting up a physical realisation but also to engage into policy dialogue and conclude bilateral agreements between governments to overcome non-physical barriers. This is to enable the harmonisation of national-based rules and standards as well as make possible the introduction of common computerized custom procedures to operate the facility.

The structural financing gap of about 45 percent for road maintenance and the risk of competing demands for maintenance as well as the potential political preference given to new investments are indications that a potential risk on long term sustainability exists.

Table 9 presents the overall scores for each evaluation criteria.

Table 9. Evaluation rating summary.

\begin{tabular}{lll}
\hline Criterion & Scores & Assessment \\
\hline Relevance & 4 & Fully relevant \\
Quality-at-entry & 2 & Unsatisfactory \\
Effectiveness & 3 & Satisfactory \\
Efficiency & 3 & Satisfactory \\
Sustainability & 2 & At risk \\
Overall Performance & 3 & Satisfactory \\
\hline
\end{tabular}

Highly satisfactory: 4; satisfactory: 3; unsatisfactory: 2; very unsatisfactory: 1.

\section{Lessons Learnt}

Alignment of development priorities of the participating countries and adequate governance arrangements are necessary conditions to ensure successful implementation of a multinational operation.

The capacity building components of a project must be consistent with the main project's rationale to be effectively implemented; otherwise they risk to be neglected.

Inadequate financial provisions for One Stop Border Post hamper the timely achievement of regional integration objectives of multinational roads.

Unless appropriate financing mechanisms for maintenance of road projects are put in place, the sustainability of reconstructed/rehabilitated roads remains at risk.

Lack of adequate monitoring and evaluation prevents a timely evaluation of the outcomes and impacts of the 
roads. This is a recurrent lesson.

\section{References}

[1] Republic of Kenya Ministry of Transport (2009) Integrated National Transport Policy: Moving a Working Nation.

[2] AICD (2009) Improving Connectivity: Investing in Transport Infrastructure in Sub-Saharan Africa. Background Paper.

[3] EAC (2007) Treaty for the Establishment of the EAC (2007 Update).

[4] EAC (2001) EAC 2001-2005 Development Strategy.

[5] EAC (2006) EAC 2006-2010 Development Strategy.

[6] Republic of Kenya Ministry of Trade and Industries (2005) Handbook on Importing and Exporting in Kenya.

[7] African Development Fund (2006) Arusha-Namanga-Athi River Development Project. Appraisal Report.

[8] AICD (2010) Kenya's Infrastructure: A Continental Perspective. Country Report.

[9] AICD (2010) Tanzania’s Infrastructure: A Continental Perspective. Country Report.

[10] Japan International Cooperation Agency, Padeco, Mitsubishi UFJ Research \& Consulting (2009) The Research on the Cross-Border Transport Infrastructure: Phase 3. Final Report.

[11] GIBB Africa Consulting, Techsult (2005) Multinational Arusha-Namanga-Athi River Development Project. Phase 1, Feasibility Study and Preliminary Engineering Design. Volume 3: Final Economic Report.

[12] GIBB Africa Consulting, Techsult (2006) Multinational Arusha-Namanga-Athi River Development Project. Phase 1, Feasibility Study and Preliminary Engineering Design. Addendum to Volume 3: Final Economic Report.

[13] EAC (2011) Arusha-Namanga-Athi River Development Project. Meeting of the Steering Committee to Review the Progress of Project Implementation.

[14] AfDB (2005) Kenya 2005-2007 Country Strategy Paper (CSP).

[15] AfDB (2006) Tanzania 2002-2004 Country Strategy Paper (CSP). Update 2006.

[16] GIBB Africa Consulting, Techsult (2006) Multinational Arusha-Namanga-Athi River Development Project. Phase 2, Final Engineering Report. Volume 1D, Athi River-Namanga Section.

[17] ADF (2010) Multinational Arusha-Namanga-Athi River Development Project. Environmental and Social Impact Assessment Summary.

[18] Marjt, S. and Mukherjee, A. (2010) Domestic Entry, International Trade Cost Reduction and Welfare. Research Paper 2010/26.

[19] COMESA, EAC, SADC (2011) Memorandum of Understanding on Inter Regional Cooperation and Integration among COMESA, EAC and SADC.

[20] COMESA, EAC, SADC (2011) Tripartite FTA Negotiating Principles, Processes and Institutional Framework. Annex I.

[21] European Conference of Ministries of Transport (2001) Assessing the Benefits of Transport.

[22] The United Republic of Tanzania Ministry of Finance and Economic Affairs (2010) National Strategy for Growth and Reduction of Poverty II (NSGRP II).

[23] The United Republic of Tanzania Ministry of Finance and Economic Affairs (2013) Economic Survey 2013.

[24] WTO (2004) World Trade Report 2004. II Coherence. B-Infrastructure in Trade and Economic Development.

[25] COMESA, EAC, SADC (2011) Declaration of Launching the Negotiations for the Establishment of the Tripartite Free Trade Areas.

[26] AfDB (2007) Tanzania. Joint Assistance Strategy and Joint Programme Document.

[27] Hirschmann, A.O. (1967) Development Projects Observed. The Brookings Institution, Washington DC.

[28] The United Republic of Tanzania Ministry of Communications and Transport (2003) National Transport Policy.

[29] Roads Fund Board—Tanzania (2011) Proposal to Widen Revenue Base for the Road Fund. 
Appendix 1. Multinational Tanzania/Kenya: Arusha Namanga Athi River Road Map

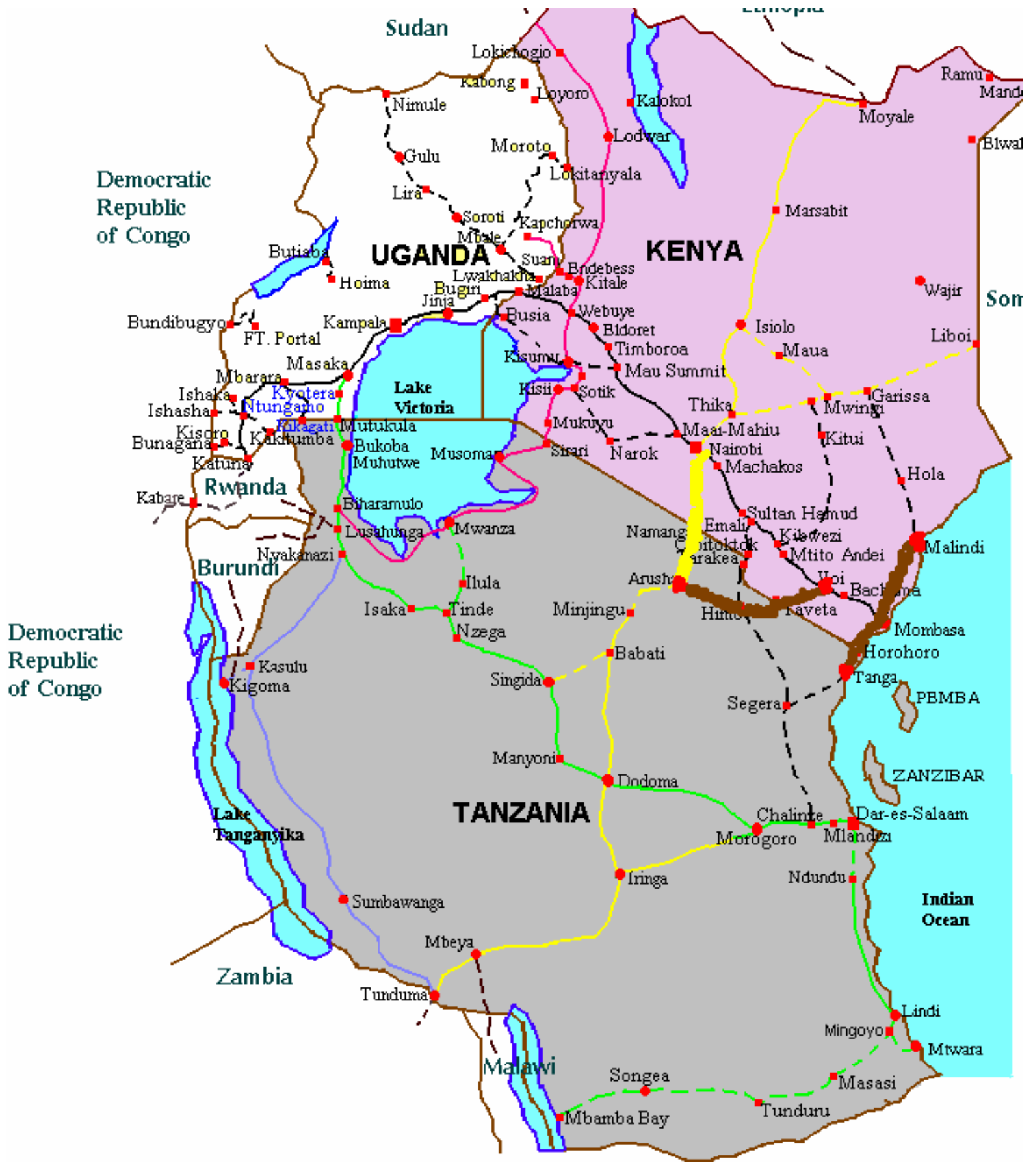




\section{Appendix 2: Interviews with Private Sector}

\section{A. Questionnaire}

Name of the Company:

Respondent title and name:

Date of interview:

\section{Participatory approach}

1) Have you been engaged/consulted by AfDB prior to the initiation of the project?

a) What level of consultation took place: individual meetings, seminars with your sectorial association, direct consultations with AfDB, etc.?

b) Does the consultation take place at different stage: identification, design, implementation, post-completion?

\section{Relevance}

2) Provide ranking on the following [1st, 2nd, 3rd] based on how your members perception regarding the leading challenge to private sector development in the region

a) Infrastructural bottlenecks.

b) Policy (customs, monetary, sectoral).

c) Political.

3) Compared with other "infrastructural" needs, was this project a top priority for your business operations

a) What other "infrastructural needs" you considered to be of top priority for your company?

b) What were the main challenges faced by the business community prior to the project?

4. How do you rate political commitment of the regional member countries on accelerating economic integration in the region under the EAC framework?

a) In terms of sustaining the results of infrastructural regional projects?

b) In terms of other non-infrastructural areas? (Policy reforms and project implementation).

\section{Effectiveness}

5) What specific economic and social benefits have materialized because of this project? (or expectation given your business experience):

a) Tourism industry (for tour companies).

- Transport costs (vehicle operating costs).

- Improved road services (travel time).

- Enhanced tourism in Arusha region and Tsavo in Kenya.

b) Cross border trading (manufacturing-export companies).

- Transport costs (vehicle operating costs).

- Improved road services (road roughness; travel time).

- Increased volume of motorized traffic/business volume.

c) Population (Kajiado and Nairobi districts).

- Transport costs (vehicle operating costs).

- Improved road services (travel time).

- Increased businesses activities along the road.

6) What factors do you perceive to be cause of success/failure of regional projects?

a) What do you think are the necessary conditions for the sustainability and for the regional operations to achieve their full benefits?

b) Do you think these factors are "considered/taken into account" by donors and/or member governments when undertaken regional initiatives?

\section{B. Results}

Based on the discussions with stakeholders, the following ratings ${ }^{4}$ were generated from each interviewee. The main criteria are three, each with three sub-criteria. The table below presents an overall assessment followed by individual assessment from each of the 8 firms.

${ }^{4}$ Rating scale: 1 = fully unsatisfactory; 2 = unsatisfactory; 3 = satisfactory; 4 = fully satisfactory. 


\section{A.-E. Gakusi et al.}

Summary of the assessment

\begin{tabular}{|c|c|c|c|}
\hline Criteria & Sub-criteria & & Ratings \\
\hline \multirow[t]{4}{*}{ Participatory } & Consulted on the project & & 1 \\
\hline & Consulted on development initiatives & & 1 \\
\hline & Influencing project design/implementation & & 1 \\
\hline & & Overall rating & 1 \\
\hline \multirow[t]{4}{*}{ Relevance } & Relevance to private sector needs & & 3 \\
\hline & Relevance at regional level & & 4 \\
\hline & Relevance at country level & & 3 \\
\hline & & Overall rating & 3 \\
\hline \multirow[t]{4}{*}{ Effectiveness } & Vehicle operating costs & & 4 \\
\hline & Road service (travel time) & & 4 \\
\hline & Business volume & & 4 \\
\hline & & Overall rating & 4 \\
\hline \multicolumn{4}{|l|}{ Firm 1} \\
\hline Criteria & Sub-criteria & & Ratings \\
\hline \multirow[t]{4}{*}{ Participatory } & Consulted on the project & & 1 \\
\hline & Consulted on development initiatives & & 2 \\
\hline & Influencing project design/implementation & & 1 \\
\hline & & Overall rating & 1 \\
\hline \multirow[t]{4}{*}{ Relevance } & Relevance to private sector needs & & 4 \\
\hline & Relevance at regional level & & 4 \\
\hline & Relevance at country level & & 4 \\
\hline & & Overall rating & 4 \\
\hline \multirow[t]{4}{*}{ Effectiveness } & Vehicle operating costs & & 4 \\
\hline & Road service (travel time) & & 4 \\
\hline & Business volume & & 4 \\
\hline & & Overall rating & 4 \\
\hline
\end{tabular}

Firm 2

\begin{tabular}{|c|c|c|c|}
\hline Criteria & Sub-criteria & & Ratings \\
\hline \multirow[t]{4}{*}{ Participatory } & Consulted on the project & & 1 \\
\hline & Consulted on development initiatives & & 1 \\
\hline & Influencing project design/implementation & & 1 \\
\hline & & Overall rating & 1 \\
\hline \multirow[t]{4}{*}{ Relevance } & Relevance to private sector needs & & 2 \\
\hline & Relevance at regional level & & 2 \\
\hline & Relevance at country level & & 2 \\
\hline & & Overall rating & 2 \\
\hline \multirow[t]{4}{*}{ Effectiveness } & Vehicle operating costs & & 4 \\
\hline & Road service (travel time) & & 4 \\
\hline & Business volume & & 3 \\
\hline & & Overall rating & 4 \\
\hline
\end{tabular}


Firm 3

\begin{tabular}{|c|c|c|c|}
\hline Criteria & Sub-criteria & & Ratings \\
\hline \multirow[t]{4}{*}{ Participatory } & Consulted on the project & & 1 \\
\hline & Consulted on development initiatives & & 1 \\
\hline & Influencing project design/implementation & & 1 \\
\hline & & Overall rating & 1 \\
\hline \multirow[t]{4}{*}{ Relevance } & Relevance to private sector needs & & 4 \\
\hline & Relevance at regional level & & 4 \\
\hline & Relevance at country level & & 4 \\
\hline & & Overall rating & 4 \\
\hline \multirow[t]{4}{*}{ Effectiveness } & Vehicle operating costs & & 4 \\
\hline & Road service (travel time) & & 4 \\
\hline & Business volume & & 4 \\
\hline & & Overall rating & 4 \\
\hline
\end{tabular}

\begin{tabular}{|c|c|c|c|}
\hline \multicolumn{4}{|l|}{ Firm 4} \\
\hline Criteria & Sub-criteria & & Ratings \\
\hline \multirow[t]{4}{*}{ Participatory } & Consulted on the project & & 1 \\
\hline & Consulted on development initiatives & & 1 \\
\hline & Influencing project design/implementation & & 1 \\
\hline & & Overall rating & 1 \\
\hline \multirow[t]{4}{*}{ Relevance } & Relevance to private sector needs & & 2 \\
\hline & Relevance at regional level & & 2 \\
\hline & Relevance at country level & & 2 \\
\hline & & Overall rating & 2 \\
\hline \multirow[t]{4}{*}{ Effectiveness } & Vehicle operating costs & & 4 \\
\hline & Road service (travel time) & & 4 \\
\hline & Business volume & & 3 \\
\hline & & Overall rating & 4 \\
\hline \multicolumn{4}{|l|}{ Firm 5} \\
\hline Criteria & Sub-criteria & & Ratings \\
\hline \multirow[t]{4}{*}{ Participatory } & Consulted on the project & & 1 \\
\hline & Consulted on development initiatives & & 1 \\
\hline & Influencing project design/implementation & & 1 \\
\hline & & Overall rating & 1 \\
\hline \multirow[t]{4}{*}{ Relevance } & Relevance to private sector needs & & 2 \\
\hline & Relevance at regional level & & 4 \\
\hline & Relevance at country level & & 1 \\
\hline & & Overall rating & 2 \\
\hline \multirow[t]{4}{*}{ Effectiveness } & Vehicle operating costs & & 2 \\
\hline & Road service (travel time) & & 2 \\
\hline & Business volume & & 2 \\
\hline & & Overall rating & 2 \\
\hline
\end{tabular}




\section{A.-E. Gakusi et al.}

Firm 6

\begin{tabular}{|c|c|c|c|}
\hline Criteria & Sub-criteria & & Ratings \\
\hline \multirow[t]{4}{*}{ Participatory } & Consulted on the project & & 1 \\
\hline & Consulted on development initiatives & & 1 \\
\hline & Influencing project design/implementation & & 1 \\
\hline & & Overall rating & 1 \\
\hline \multirow[t]{4}{*}{ Relevance } & Relevance to private sector needs & & 2 \\
\hline & Relevance at regional level & & 2 \\
\hline & Relevance at country level & & 2 \\
\hline & & Overall rating & 2 \\
\hline \multirow[t]{4}{*}{ Effectiveness } & Vehicle operating costs & & 4 \\
\hline & Road service (travel time) & & 4 \\
\hline & Business volume & & 4 \\
\hline & & Overall rating & 4 \\
\hline
\end{tabular}

\begin{tabular}{|c|c|c|c|}
\hline Criteria & Sub-criteria & & Ratings \\
\hline \multirow[t]{4}{*}{ Participatory } & Consulted on the project & & 1 \\
\hline & Consulted on development initiatives & & 1 \\
\hline & Influencing project design/implementation & & 1 \\
\hline & & Overall rating & 1 \\
\hline \multirow[t]{4}{*}{ Relevance } & Relevance to private sector needs & & 3 \\
\hline & Relevance at regional level & & 3 \\
\hline & Relevance at country level & & 3 \\
\hline & & Overall rating & 3 \\
\hline \multirow[t]{4}{*}{ Effectiveness } & Vehicle operating costs & & 4 \\
\hline & Road service (travel time) & & 4 \\
\hline & Business volume & & 4 \\
\hline & & Overall rating & 4 \\
\hline
\end{tabular}

Firm 8

\begin{tabular}{|c|c|c|c|}
\hline Criteria & Sub-criteria & & Ratings \\
\hline \multirow[t]{4}{*}{ Participatory } & Consulted on the project & & 1 \\
\hline & Consulted on development initiatives & & 1 \\
\hline & Influencing project design/implementation & & 1 \\
\hline & & Overall rating & 1 \\
\hline \multirow[t]{4}{*}{ Relevance } & Relevance to private sector needs & & 4 \\
\hline & Relevance at regional level & & 4 \\
\hline & Relevance at country level & & 4 \\
\hline & & Overall rating & 4 \\
\hline \multirow[t]{4}{*}{ Effectiveness } & Vehicle operating costs & & 3 \\
\hline & Road service (travel time) & & 4 \\
\hline & Business volume & & 3 \\
\hline & & Overall rating & 3 \\
\hline
\end{tabular}




\section{Appendix 3. Project Institutional and Organisational Framework}

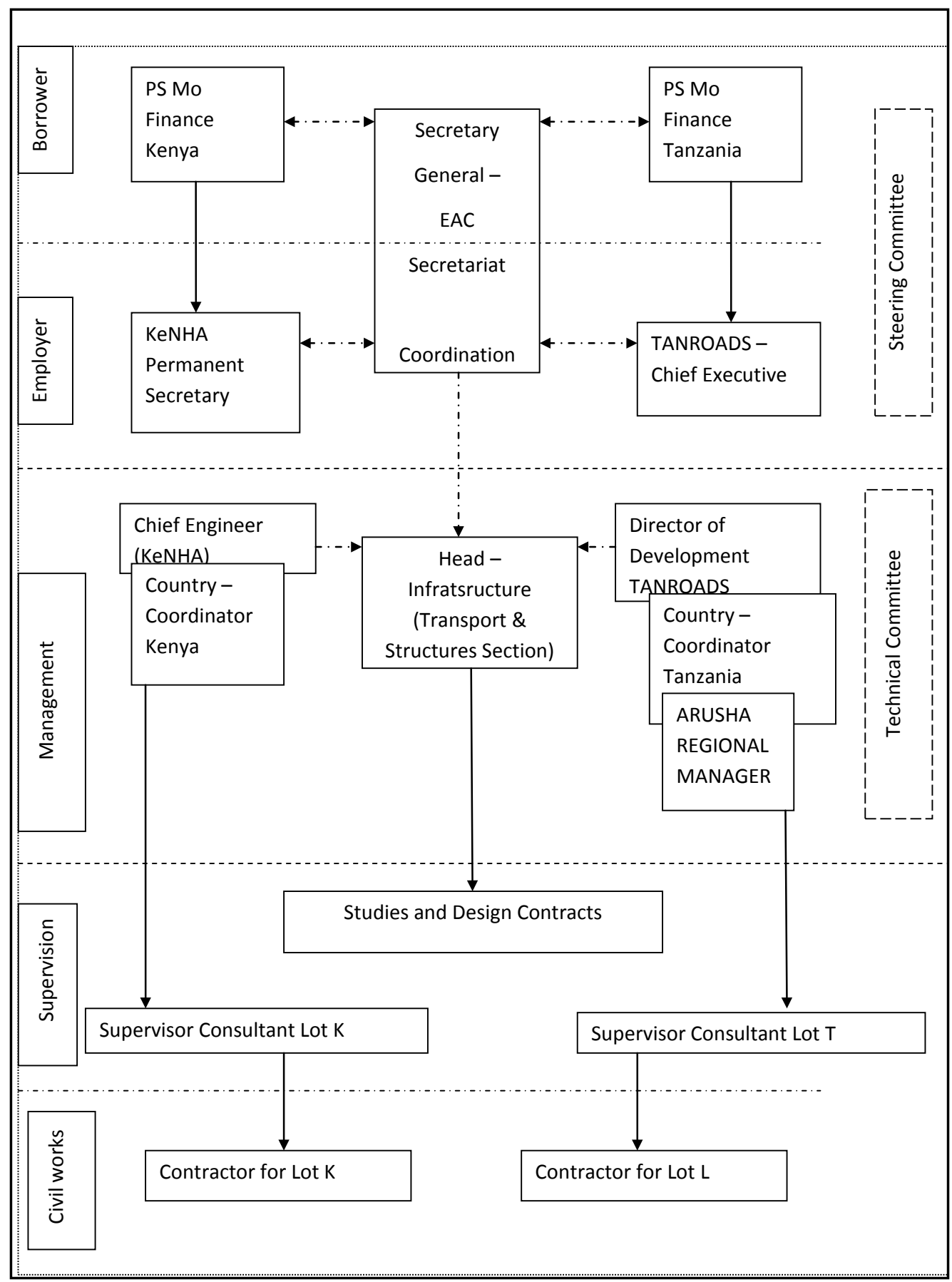


Appendix 4. Evaluation Check List

\begin{tabular}{|c|c|c|}
\hline Topic & Evaluation Questions & Source of Information \\
\hline $\begin{array}{c}\text { Context and } \\
\text { intervention logic }\end{array}$ & $\begin{array}{l}\text { - Was the development challenge addressed by the project a real priority } \\
\text { - } \quad \text { Who are the stakeholders involved and what are their roles? What are } \\
\text { the interests and motives of different actors? } \\
\text { - } \quad \text { Is the political, cultural, socio-economic, institutional, regulatory } \\
\text { context playing a role in influencing the attainment of benefits? } \\
\text { - Are there any political, social, cultural, economic, regulatory, or } \\
\text { institutional constraints? }\end{array}$ & $\begin{array}{ll}\text { - } & \text { East African Community } \\
\text { - } & \text { Coordinating Agency } \\
\text { - } & \text { Ministry of works in Tanzania } \\
\text { - } & \text { Ministry of Finance in Tanzania } \\
\text { - } & \text { Ministry of roads in Kenya } \\
\text { - } & \text { Municipalities } \\
\text { - } & \text { Civil society }\end{array}$ \\
\hline $\begin{array}{c}\text { Relevance and } \\
\text { QaE }\end{array}$ & $\begin{array}{l}\text { - Was the project design of such a good quality to be a key factor for the } \\
\text { future success of the project? } \\
\text { - On which dimensions of project design and preparation (e.g. } \\
\text { governance structure, economic viability, implementation } \\
\text { arrangements, etc.) have resources and efforts been mainly spent? } \\
\text { - } \quad \text { Were the ex-ante forecasts based on a sound methodology and a } \\
\text { comprehensive set of information? } \\
\text { - } \quad \text { On which aspects was the project design and preparation weaker? } \\
\text { Were there some important factors not sufficiently considered } \\
\text { ex-ante? } \\
\text { - Was there an indication in the project design of how future welfare } \\
\text { gains will split between the two countries? } \\
\text { To what extent is this distribution of benefits and costs between } \\
\text { participating countries fair? } \\
\text { Are there winners and losers? }\end{array}$ & $\begin{array}{ll}\text { - } & \text { East African Community } \\
\text { - } & \text { Coordinating Agency } \\
\text { - } & \text { KENROADS } \\
\text { - } & \text { J. Burrow } \\
\text { - } & \text { GIBB Africa }\end{array}$ \\
\hline Effectiveness & $\begin{array}{l}\text { - Is the project fostering regional integration by facilitating the } \\
\text { exchange of goods and services between countries? Is it removing } \\
\text { barriers to trade? Is it reducing travel time for freight and passengers? } \\
\text { - } \quad \text { Is it playing a role in harmonizing legal and procedural systems? Is it } \\
\text { increasing territorial cohesion within the region through } \\
\text { urban-rural or core/periphery or cross-border dynamics? } \\
\text { - } \quad \text { Is it inducing any institutional learning in the countries and in the } \\
\text { REC? Is it raising political awareness of countries over the theme of } \\
\text { the regional integration? Is it having effects on the level of corruption? } \\
\text { - Does a causal relationship exist between the future benefits and the } \\
\text { arrangement for governance/stakeholders' involvement? } \\
\text { - What arrangements have the project management put in place to } \\
\text { promptly react to exogenous, unpredictable, events? What remedial } \\
\text { actions have been foreseen? } \\
\text { Have there been any unexpected events? If yes, were they due to their } \\
\text { purely exogenous nature? Or, was it due to poor planning capacity? }\end{array}$ & $\begin{array}{ll}\text { - } & \text { East African Community } \\
\text { - } & \text { Coordinating Agency } \\
\text { - } & \text { Ministry of work in Tanzania } \\
\text { - } & \text { The Ministry of Finance in } \\
& \text { Kenya } \\
\text { - } & \text { Ministry of roads In Kenya } \\
\text { - } & \text { TANROADS } \\
\text { - } & \text { KENhA } \\
\text { - } & \text { Municipalities } \\
\text { - } & \text { Civil society }\end{array}$ \\
\hline Efficiency & $\begin{array}{l}\text { - Is the project suffering cost overrun? } \\
\text { - } \quad \text { Is the project suffering delays in implementation? } \\
\text { - In the case the actual investment cost is higher than excepted, is the } \\
\text { economic net present value still positive? } \\
\text { - Are contractual arrangements in place improving the co-ordination of } \\
\text { different stakeholders towards achievement-oriented results? } \\
\text { - What are the forms of the contract (legal or implicit)? }\end{array}$ & $\begin{array}{ll}\text { - } & \text { East African Community-Head } \\
& \text { Infrastructure } \\
\text { - } & \text { EAC Engineers } \\
\text { - } & \text { TANROADS } \\
\text { - } & \text { KENhA } \\
\text { - } & \text { J. Burrow } \\
\text { - } & \text { GIBB Africa } \\
\text { - } & \text { China Geo }\end{array}$ \\
\hline Sustainability & $\begin{array}{l}\text { - How will maintenance of the road be assured? } \\
\text { - What are the main sources of difficulty/obstacles to maintain results in } \\
\text { the long run? }\end{array}$ & $\begin{array}{ll}\text { - } & \text { Tanzania Road Fund } \\
\text { - } & \text { Kenya Roads Board } \\
\text { - } & \text { EAC }\end{array}$ \\
\hline $\begin{array}{c}\text { Bank } \\
\text { performance }\end{array}$ & $\begin{array}{l}\text { - } \quad \text { Have Bank procedures facilitated the project implementation? } \\
\text { - Have recipient countries and executing agencies complained about the } \\
\text { - } \quad \text { What arrangements has the Bank put in place to promptly react to } \\
\text { exogenous, unpredictable, events? } \\
\text { - } \quad \text { How has the Bank project component performed in comparison with } \\
\text { other project components? } \\
\text { - What was the role of the Bank in the overall project conception and } \\
\text { design? } \\
\text { What role played the Bank in establishing a political dialogue with the } \\
\text { government of the concerned countries? }\end{array}$ & $\begin{array}{ll}\text { - } & \text { EAC } \\
\text { - } & \text { AfDB Regional Offices } \\
\text { - } & \text { TANROADS } \\
\text { - } & \text { KENha }\end{array}$ \\
\hline
\end{tabular}


Appendix 5. Bank's Portfolio in Kenya and Tanzania, 2000-2010

\begin{tabular}{cccccc}
\hline & Kenya & & \multicolumn{3}{c}{ Tanzania } \\
\hline Sector & Amount (UA 000) & \% & Sector & Amount (UA 000) & \% \\
\hline Transport & $385,040.0$ & 39.5 & Transport & $271,887.0$ & 26.8 \\
Water Sup/Sanit. & $170,260.0$ & 17.5 & Multi-Sector & $249,997.0$ & 24.6 \\
Power & $136,470.0$ & 14.0 & Water Sup/Sanit. & $201,521.0$ & 19.9 \\
Agriculture & $125,519.1$ & 12.9 & Agriculture & $105,660.0$ & 10.4 \\
Social & $101,843.4$ & 10.5 & Social & $102,390.0$ & 10.1 \\
Multi-Sector & $33,729.3$ & 3.5 & Power & $77,230.0$ & 7.6 \\
Environment & $16,480.0$ & 1.7 & Finance & $6,040.0$ & 0.6 \\
Finance & $4,419.6$ & 0.5 & Environment & - & - \\
Total & $\mathbf{9 7 3 , 7 6 1 . 4}$ & $\mathbf{1 0 0 . 0}$ & Total & $\mathbf{1 0 1 4 , 7 2 5 . 0}$ & $\mathbf{1 0 0 . 0}$ \\
\hline
\end{tabular}

Source: AfDB data bases. 